\title{
AN INTRODUCTION TO EXPLORING LAW, DISABILITY, AND THE CHALLENGE OF EQUALITY IN CANADA AND THE UNITED STATES: PAPERS FROM THE BERKELEY SYMPOSIUM
}

\author{
Laverne Jacobs ${ }^{*}$ \\ Editor-in-Chief, Windsor Yearbook of Access to Justice
}

It brings me great pleasure to write this Introduction to Exploring Law, Disability, and the Challenge of Equality in Canada and the United States. This special collection of articles in the Windsor Yearbook of Access to Justice [WYAJ] stems from a symposium of the same name held at the Berkeley Law School at the University of California on 5 December 2014. Writing this introduction allows me to bring together my identities as a law and disability scholar, the principal organizer and convener of the Berkeley Symposium, and editor-in-chief of the WYAJ. In these roles, I have had the opportunity to engage with this set of articles and their authors in a distinct way - from the early versions of these articles through to the final peer-reviewed publications. The Berkeley Symposium is the first conference, of which we are aware, to bring together scholars and experts from both Canada and the United States to present research and exchange ideas on equality issues affecting persons with disabilities in both countries. ${ }^{1}$ Each academic was invited to write about an equality issue of their choice that is of contemporary concern to persons with disabilities, and to focus on Canada, the United States, or both, at their option. The result is a set of articles that is simultaneously introspective and comparative.

The symposium papers fall within the emerging field of Disability Legal Studies, a school of thought initiated by Sagit Mor. ${ }^{2}$ The field of Disability Legal Studies is an inherently interdisciplinary one. It invites us to consider what Mor elegantly terms the "constitutive role of law in the production of disability." " Disability Legal Studies asks us to think about, and critically evaluate, how law engages with and reflects the lived experiences of persons with disabilities, how the law does and should regulate the lives of persons with disabilities, and how persons with disabilities can induce change in policy and legislation. ${ }^{4}$

The vision of the symposium, and of this resulting WYAJ special collection, is to explore some of the possibilities and nuances of Disability Legal Studies by focusing on the notion of equality. What does equality mean in the context of Disability Legal Studies? How can a legal

\footnotetext{
Associate Professor and Director of Graduate Studies, Faculty of Law, University of Windsor. At the time of the Berkeley Symposium, I had the honour of holding the Fulbright Visiting Research Chair in the Canadian Studies Program at University of California Berkeley and of being a visiting scholar at the Center for the Study of Law and Society at Berkeley Law.

1 A video and archive of the Berkeley Symposium are available at online: Berkeley Law $<$ https://www.law.berkeley.edu/law-and-disability-conference $>$.

2 See Sagit Mor, "Between Charity, Welfare, and Warfare: A Disability Legal Studies Analysis of Privilege and Neglect in Israeli Disability Policy" (2006) 18:1 Yale J L \& Humanities 63.

$4 \quad$ See also Arlene S Kanter, "The Law: What's Disability Studies Got to Do with It or an Introduction to Disability Legal Studies" (2011) 42 Columbia Human Rights L Rev 403 who refers to the "disability angles" of the law.
}

$3 \quad$ Ibid at 64. 
promise of equality deliver what American Jacobus tenBroek termed in 1966 "a policy entitling the disabled to full participation in the life of the community and encouraging and enabling them to do so" or achieve what Canadian disability legal rights scholars Diane Pothier and Richard Devlin have called "an anti-necessitarian understanding of disability that focuses on genuine inclusiveness, not just abstract rights." How can the concept of equality be developed in and through the law to effect social and legal change for persons with disabilities?

The articles in this special issue speak implicitly and overtly to the constitutive role that law plays in developing, shaping, and asserting (often impertinently, if not unseeingly) what it is to be "disabled" in society. All offer rich illustrations of legal situations that pose significant barriers to individuals with impairments. These legal phenomena could be conceived in ways that reduce barriers to persons with disabilities in society. The authors work on ways of thinking about how to chip away at these barriers - sometimes by focusing on a deeper, empirical understanding of the phenomenon itself and often with contemplation of what is done in the other North American jurisdiction. In doing so, they propose solutions that effectively interweave disability legal theory and practice.

The articles bring forward three themes. The first theme evaluates the achievements and challenges that continue to face persons with disabilities in their struggles for equality within the broad context of social and economic rights and particularly with respect to movement across borders and the definition of capacity to consent. In "Immigration and Disability in the United States and Canada," Mark Weber discusses several barriers related to entry, deportation, and citizenship faced by persons with disabilities as a result of the construction of immigration laws in both Canada and the United States. ${ }^{7}$ Taking a view through the lens of the social model of disability, he concludes that despite the removal of several exclusions from entry in both Canada and the United States, and in spite of accommodations relating to the acquisition of citizenship, numerous challenges continue in both jurisdictions owing in part to the discretion of immigration officials. Weber's comprehensive examination, which cannot be given justice in this brief overview, ends with reference to the United Nations Convention on the Rights of Persons with Disabilities [CRPD], which offers the promise of stronger recognition of disability discrimination in the context of mobility rights. ${ }^{8}$

The CRPD promises equally the freedom to make one's own choices. ${ }^{9}$ More specifically, subArticles 12 (2), (3), and (4) raise the issue of legal capacity, asserting, among other things, that persons with disabilities should enjoy legal capacity on an equal basis with others and receive the support required to do so. Eniola Salami and Bonnie Lashewicz's contribution to this issue informs the very important and pressing question of what support for legal capacity means in the

Jacobus tenBroek, "The Right to Live in the World: The Disabled in the Law of Torts" (1966) 54 Cal L Rev 841 at 843 .

6 Dianne Pothier and Richard Devlin, eds, Critical Disability Theory: Essays in Philosophy, Politics, Policy, and Law (Vancouver: UBC Press, 2006) at 2.

7 Mark Weber, "Immigration and Disability in the United States and Canada" (2015) 32 Windsor YB Access Just 19.

8 Convention on the Rights of Persons with Disabilities, GA Res 61/106 UNGAOR, $61^{\text {st }}$ Sess, Supp No 49, UN Doc Convention on the Rights of Persons with Disabilities A/Res61/106 (2007) 2.

9 See ibid, art 3a. 
context of adults with developmental disabilities. Their article, "More Than Meets the Eye: Relational Autonomy and Decision-Making by Adults with Developmental Disabilities," presents the results of a qualitative field research study in which they examined the dynamics and implications of relational autonomy in decision making by studying adults with developmental disabilities in interaction with their caregiving family members. ${ }^{10}$ Salami and Lashewicz's study is thoughtfully situated within a broader theoretical inquiry into the nature of relational autonomy as drawn from feminist theory. Recognizing that further research could complement this area of inquiry, the authors rely on the study's findings to develop a framework that begins to explore how family caregiving relational contexts both support and hinder decision making by adults with developmental disabilities.

The second theme analyzes the $C R P D$ as a legal instrument designed to combat disability discrimination and further the socio-economic empowerment of persons with disabilities. Since its entry into force on 3 May 2008, the CRPD has had over 160 ratifications, representing over 80 percent of all UN member states. ${ }^{11}$ It is well known that Canada ratified the $C R P D$ in 2010 and that the United States has yet to ratify the convention. Yet, does the existence of the CRPD have any impact or influence on US decision making? Is it brought forward by American attorneys or raised by American courts in disability rights claims and, if so, how is it treated? In his article, "The United Nations Convention on the Rights of Persons with Disabilities in Canadian and American Jurisprudence," Ravi Malhotra explores, among other issues, this very interesting question. ${ }^{12}$ On both sides of the border, he finds few decisions in the still emerging jurisprudence but, surprisingly, two US decisions that have maintained that "the international adoption of disability rights ought to be accorded persuasive weight in the interpretation of domestic law." " Other American courts have simply declined any use of the CRPD. Using transnational legal process and transnational judicial dialogue theory, Malhotra's comprehensive piece also discusses cases in Canada that have applied the CRPD and assesses the CRPD's potential for social transformation in the two countries.

In her article, "A Comparative View of Equality under the UN Convention on the Rights of Persons with Disabilities and the Disability Laws of the United States and Canada,"14 Arlene Kanter comparatively examines three instruments: the $C R P D$, the Americans with Disabilities Act $(A D A),{ }^{15}$ and the Canadian Charter of Rights and Freedoms, ${ }^{16}$ focusing primarily on the extent to which people with disabilities are treated equally in employment settings under their

10 Eniola Salami and Bonnie Lashewicz, "More Than Meets the Eye: Relational Autonomy and Decision-Making by Adults with Developmental Disabilities" (2015) 32 Windsor YB Access Just 91.

11 An updated list of signatories and ratifications usefully kept by the United Nations at online: United Nations $<$ https://treaties.un.org/Pages/ViewDetails.aspx?src=TREATY\&mtdsg_no=IV-15\&chapter=4\&lang=en $>$. See also Arlene Kanter's article referenced below.

12 Ravi Malhotra, "The United Nations Convention on the Rights of Persons with Disabilities in Canadian and American Jurisprudence” (2015) 32 Windsor YB Access Just 1.

13 Ibid at 16.

14 Arlene Kanter, "A Comparative View of Equality under the UN Convention on the Rights of Persons with Disabilities and the Disability Laws of the United States and Canada" (2015) 32 Windsor YB Access Just 65.

15 Pub L No 101-336, 104 Stat 327 (codified as amended at 42 USC $§ 12101 \mathrm{ff}(2010)$ ).

16 Part I of the Constitution Act, 1982, being Schedule B to the Canada Act 1982 (UK), 1982, c 11. 
domestic laws. After setting out an extensive analysis of three predominant models of equality that the law uses in relation to people with disabilities, she argues that both US and Canadian legislatures and courts should look to the CRPD to help move beyond traditional notions of formal equality towards a right to substantive equality in the workplace for people with disabilities.

The third and final theme considers disability advocacy, its human and monetary impacts, and how social change may be effected through procedural design. In "Advocacy Fatigue: Self-Care, Protest, and Educational Equity," Carrie Griffin Basas discusses the material, psychological, and social impact on families that must advocate for their students in the US educational system. ${ }^{17}$ She asserts as a fundamental premise that the "need for self-advocacy and community organizing toward inclusion as educational equity is a constant in the lives of people on the social margins." 18 Yet the impact on the family of a person with disabilities and others seeking educational equity is often overlooked. Instead, the focus of discussions about special education is usually placed on the educator. Basas defines a new term - "advocacy fatigue" - which goes beyond litigation stress to address, more holistically, the increased strain on emotional, physical, material, social, and wellness resources that comes from continued exposure to system inequities and inequalities. Furthermore, she proposes collaborative strategies for moving educational equity forward. These strategies include resistance, self-care, community wholeness, and professional development.

Stephen Rosenbaum also engages with the effects of adversarial legalism in the context of special education litigation but by way of a direct critique of the decision-making system itself. In "Une Procédure en Difficulté: A Blueprint for Resolving 'Special' Education Disputes through a Quasi-Inquisitorial Administrative Process," Rosenbaum reflects on instances where family and school authorities disagree about the components of a student's special education instructional program. ${ }^{19}$ Drawing inspiration from the ways in which inquisitorial processes have been brought into administrative law regimes in Canada and elsewhere in the Commonwealth, Rosenbaum suggests radical change for special education hearing processes under the US Individuals with Disabilities Education Act $[I D E A] .{ }^{20} \mathrm{He}$ proposes that IDEA's adversarial hearing model be replaced by an active adjudication model in which a "special master" whose expertise is in education or disability, rather than law, would use some of the typical tools of a non-adversarial process to quickly resolve disputes over appropriate placement, instructional strategies, and/or services. The tools identified by Rosenbaum include holding conferences, conducting brief investigations, receiving more documents, and so on. Rosenbaum maintains that a quasi-inquisitorial process and culture will bring savings in time and costs and reduce angst to families. Ultimately, the savings in public school funds and energy could be diverted towards such positives as specialist teaching personnel and collaborative educational planning. Although

17 Carrie Griffin Basas, "Advocacy Fatigue: Self-Care, Protest, and Educational Equity” (2015) 32 Windsor YB Access Just 37.

$18 \quad$ Ibid at 38.

19 Stephen A Rosenbaum, "Une Procédure en Difficulté: A Blueprint for Resolving 'Special' Education Disputes through a Quasi-Inquisitorial Administrative Process" (2015) 32 Windsor YB Access Just 115.

20 Pub L No 108-446, 118 Stat 2647 
some may not agree with Rosenbaum's approach as it places decision making in persons other than the individual with a disability or their family, ${ }^{21}$ it does raise interesting and thoughtful comments on how law creates vulnerability in the student of special education and their family through an adversarial process in which they may be subjected to significant power and other imbalances.

My thanks to all of the contributors to this project including my wonderful colleagues at University of California Berkeley on the organizing committee - Irene Bloemraad, Susan Schweik, and Rosann Greenspan - and to the sponsors of the Berkeley Symposium. ${ }^{22}$ The result is without a doubt a provocative, inspiring, and practical contribution to Disability Legal Studies and disability advocacy. It is no accident that the Berkeley Symposium was held on the eve of the twenty-five-year anniversary of the $A D A$ and ten-year anniversary of the Accessibility for Ontarians with Disabilities Act, $2005,{ }^{23}$ two pieces of legislation, one from the United States and one from Canada, that have made strides in attempting to achieve equality for persons with disabilities. The articles in this issue present a unique and modern contribution to the law and disability literature. As a comparative project, this contribution is just the beginning. Hopefully, what Canada and the United States, neighbouring jurisdictions, can learn from each other about the ways in which they address disability equality issues will inspire future conferences, literature, and action.

21 Rosenbaum pre-emptively addresses these critiques in his article. See ibid, Part X: "Objections to New Model."

22 The sponsors were the Canadian Studies Program, University of California, Berkeley; Disability Studies Cluster and the Diversity and Democracy Cluster of the Haas Institute for a Fair and Inclusive Society, University of California, Berkeley; the Center for the Study of Law and Society, Berkeley Law, University of California, Berkeley; and the Faculty of Law at the University of Windsor, Canada.

23 SO 2005, c 11. 